\title{
Martin Prozesky and 'Well-being': Retroactive and Proactive Perspectives on Religion and Ethics in the Social Transformation of South Africa
}

\author{
Johannes A. Smit \\ smitj@ukzn.ac.za
}

\author{
Denzil Chetty \\ chettd@unisa.ac.za
}

\section{Abstract}

This article primarily outlines the discursive threads in Prozesky's 'Implications of Apartheid for Christianity in South Africa' in the book he edited, Christianity Amidst Apartheid: Selected Perspectives on the Church in South Africa ([1985] 1990); his first book, Religion and Ultimate Well-Being: An Explanatory Theory (1984); and his latest book, Conscience: Ethical Intelligence for Global Well-Being (2007). This is under three headings: Apartheid as Heresy; Explaining Religion; and Conscience Ethics. We conclude with some appreciative and critical reflections, that we believe, can take Prozesky's life-long project, further. This is positioned in the social transformation paradigm.

Keywords: well-being, apartheid as heresy, explain religion, conscience ethics, religion and social transformation

\section{Introduction}

It is through Smit's friendship with a former colleague of his, that he was introduced to the work of Prof. Martin Prozesky and Process Philosophy in the 
early 1990s. The colleague, Alrah Pitchers, then lecturing in Systematic Theology, was doing his PhD under the supervision of Prozesky on the muchcontested Christology of Hans Küng. His critique of Küng, was that he should have supplemented his focus on Hegel's notion of 'becoming' by using or drawing on results of especially German New Testament scholarship based on the application of the historical-critical method, with process thought. (This was in the midst of the so-called Third Quest of the Historical Jesus.) Then in the early 2000s, we had occasion to interact with Martin as a fellow member of the Association for the Study of Religion in Southern Africa when we joined. It is at this point that we started to sporadically read some of Martin's work, and also prescribed some of his work in the then recently founded University of KwaZulu-Natal (2004), Howard College Campus in Durban (cf. esp. Prozesky 1990a; de Gruchy \& Prozesky 1991; Prozesky and de Gruchy 1995). At the joint conference of 2009 at Stellenbosch, we suggested the idea of a Festschrift to him. And, as they say, the rest is history.

As one of the most significant scholars of Religion and Ethics in South Africa, we found Prozesky's work as indispensable for the teaching of the religions in the pluralist religious and moral/ ethical framework we introduced at Howard College in $2004^{1}$. So, for many - both colleagues and students in the then Faculty of Humanities - it was a breath of fresh air to offer Comparative Religion modules that include the study of all the major religions, especially African Religion, (African) Christianity, Hinduism (in South Africa), and Islam (in South Africa), critically reflecting on the challenging socio-cultural, socio-political and socio-economic issues we face in our postcolonial and especially post-apartheid contexts, and, that, on an equal footing. The phenomenal, progressive growth of enrolment in the modules and student rationales for enrolling for the modules, and their evaluations testify to this fact ${ }^{2}$. To our mind, Prozesky has, through his just over fifty years of

${ }^{1}$ Previously, only contemporary Jewish Studies was offered for some years, at this campus, but that was closed in the late 1990s due to a dearth of students. No courses, to our knowledge, in 'Religion' and 'Ethics' were offered at Howard College campus, in the then nearly one hundred years of the existence of the previous University of Natal.

${ }^{2}$ Cf. Smit \& Vencatsamy (2012) for an overview of both statistical enrolments of a representative sample of modules, student rationales, and evaluations, $2005-2010$. 
scholarship, opened the way for us, to walk this road, and to continue to add to the continuously growing scholarship about the religions in Southern Africa, but also more broadly speaking. This, in brief is also the background to why we have decided to bring together this Festschrift in honour of Prof. Martin Prozesky. We think that the work that he has done, has shown an important part of the way in terms of which we need to continue to grow our study of our still very young disciplines of Religion and Ethics in Southern Africa, but also more broadly speaking in Africa, and globally speaking.

Since a full assessment of Prozesky's thought and work is still outstanding, we shall, in this concluding chapter of the Festschrift, only briefly reflect on three topics central to his thought and publications: Apartheid as Heresy; Explaining Religion; and Conscience Ethics. To some extent, these consecutive topics reflect his intellectual 'journey' - a conceptual metaphor he uses himself (cf. Prozesky 2000). Originating in boyhood experience, and brought to maturity in his progressive quest as he lived through and critically reflected on 'Religion' and 'Ethics' in some of the most significant phases of South Africa's socio-political history, they represent important topics in his oeuvre. And, in some measure, they provide some background information towards charting the future of the study of Religion and Ethics together with him, for us, in our African context, and we shall concludingly say something about this ${ }^{3}$.

\section{Apartheid as Heresy}

Even though he grew up in a Christian home that was severely critical of apartheid, and also valued his local Anglican parish priest who was outspokenly critical of apartheid and apartheid Christianity, it was through his own intellectual endeavours that Prozesky carved out his own intellectual niche for a critique of the system of apartheid, but especially the partially Christian founding, supporting and defending of it (cf. Prozesky 2000a).

In his paper, 'Christianity and Apartheid: From Christian Deicide to Socio-Political Salvation in South Africa' at the conference on 'Salvation and the Secular', in 1985, in Pietermaritzburg, Prozesky not only reflected on the Christian religious connection to apartheid but also on the 'cause' of this

${ }^{3}$ At this point, we plan to develop these thoughts further in other publications. 
connection (Prozesky 1990a:125) ${ }^{4}$. In our assessment, it was the decision of the World Alliance of Reformed Churches (W.A.R.C.) that declared apartheid a heresy in 1982, that provided Prozesky with the opportunity to quite definitively address both these issues. ${ }^{5}$. He says as much.

Firstly, as part of its declaration, the W.A.R.C. declared the ideology of apartheid, 'a sin', that its 'moral and theological justification ... is a travesty' and that [the S.A. white reformed churches'] 'persistent disobedience to the Word of God, [is] a theological heresy' (cf. World Alliance of Reformed Churches, 1982, in de Gruchy \& Villa-Vicencio 1983:170). It further elaborated that it regarded apartheid as 'sinful and incompatible with the Gospel' in relation to the fact that:

(a) it is based on a fundamental irreconcilability of human beings, thus rendering ineffective the reconciling and uniting power of our Lord Jesus Christ;

(b) in its application through racist structures it has led to exclusive privileges for the white section of the population at the expense of the blacks;

(c) it has created a situation of injustice and oppression, largescale deportation ['forced removals'] causing havoc to family life, and suffering to millions (de Gruchy \& Villa-Vicencio 1983: 171).

At this meeting, the W.A.R.C. concomitantly also suspended the membership of the white Nederduitse Gerformeerde Kerk (NGK/ Dutch Reformed Church, DRC) and the Nederduitsch Hervormde Kerk, until such time that the following changes have taken place:

(a) Black Christians are no longer excluded from church services, especially from Holy Communion;

${ }^{4}$ The paper was subsequently published as 'Implications of Apartheid for Christianity in South Africa' (cf. Prozesky 1990a). We quote from this publication.

${ }^{5}$ The W.A.R.C. was established in 1970, and met every four years. (Presently, it is called the World Communion of Reformed Churches.) This decision was taken at its third meeting in 1982 at Ottawa in Canada. 
(b) Concrete support in word and deed is given to those who suffer under the system of apartheid ('separate development');

(c) Unequivocal synod resolutions are made which reject apartheid and commit the Church to dismantling this system in both Church and politics (de Gruchy \& Villa-Vicencio 1983: 172).

In Prozesky's appreciation but also critique, of this declaration by the W.A.R.C., he says that it has only dealt with the 'effects' of apartheid. In the words of the W.A.R.C., this means it only focuses on the effects of 'irreconcilability' in apartheid that renders the 'uniting power of ... Christ' 'ineffective'; its leading to 'exclusive privileges for the white section of the population at the expense of the blacks'; and that its 'injustice and oppression, and largescale deportation [forced removals]' causes 'havoc to family life, and suffering to millions'.

Similarly, for Prozesky (1990a), apartheid more generally is 'a system of unjust domination, exclusion and disadvantage' and can be characterised by the fact that,

the positon of black people has been legally and practically inferior to that of whites by every significant measure - access to economic power, the vote, citizenship, education, health care, life expectancy, work opportunities, income, freedom of movement, prospects of improvement and even places of worship and burial (Prozesky 1990a: 126).

The most 'simple and valid definition' that can be given to it is, he says, that,

apartheid is a legalised injustice which whites who identify strongly with Christianity have imposed by force on blacks in South Africa, the majority of whom are their fellow Christians (e.i.o.; Prozesky 1990a: 127).

For him, this is also the 'truth' and 'present and past condition' of white apartheid Christianity in South Africa (Prozesky 1990a: 123).

Staying within Christianity, for Prozesky, as for the W.A.R.C., the effects of apartheid need to be evaluated in terms of the 'criterion' Jesus and 
therefore Christianity itself propounds and advocates, in its 'central message', namely Christian 'love'. This is central to 'the life of God, in the example of Jesus, and in the path Christians commit themselves to walk' (Prozesky 1990b:124). In their 'creating, legitimating and supporting' apartheid morally and theologically though, the majority of white Afrikaner Christians have delegitimised Christianity. Prozesky (1990a:126) says:

[It is] incompatible with the commitment to love one's fellow human beings as oneself, because none of its basic features involves real equality and well-being for all South Africans.

This finding of the evaluation of white Afrikaner Christianity's support of apartheid, in his words, means that apartheid is in fact a 'killing off in some people the capacity to find God real' ... a 'deicide' (e.i.o.; Prozesky 1990a: $125)$.

Secondly, and turning from the white Afrikaner Christian relationship to the ideology of apartheid and its combined 'effects', Prozesky argues that this state of affairs - also evident in the various involvements of Christianity in the two world wars, the state church's support of Nazism in Germany and the development of nuclear weapons amongst others - is the result of a 'cause' that can be located within the 'contradictions' within orthodox Christianity itself. He then develops arguments on these contradictions concerning the following issues (cf. Prozesky 1990b: 128ff; cf. also 1985:61):

- Christianity's inadequate social impact;

- Contradictions and defects within orthodox doctrine - i.e. both the propounding of the 'love ethic' and 'salvation' are not universally inclusive;

- Erosion of Christian credibility in the matrices of meaning - it discredits itself in practice;

- Insufficient critical realism - like some other religions, it founds itself in divine revelation, which contradicts a focus on human realities;

- An unrealistic concept of religion - that at least some part(s) of religion must be ascribed to human creativity; and 
- Ecumenical disunity - Christianity does not propound a unified minimum system of Christian essentials, based on a love-centred religious philosophy.

For him, these are the 'causes' within Christianity itself, that serve as the sources that create the inhuman 'effects' of the devastating systems such as we witnessed in apartheid ${ }^{6}$.

Reflecting on the religions' importance for building an ethic for postapartheid South Africa, especially Christianity, since it represents three quarters of the total population of the country, he proposes the developing of an ethic that provides 'equal rights, opportunities and safety for all' (p. 122). Such an ethic would 'transform' South Africa into 'a post-apartheid society with equality and well-being for all' - 'values which promote the greatest egalitarian well-being of all our people' (e.i.o.; Prozesky 1990a:124, 126f). This would lead to 'national political salvation' (Prozesky 1990a:141).

\section{Explaining Religion}

Parallel to Prozesky's growing up critical of apartheid was also his consciousness of the diversity or plurality of religions. He grew up in a place with a large Jewish community in which he was to find his best friend. As student, he encountered fellow Hindu and Buddhist students, and as lecturer in Zimbabwe (since 1969) he experienced sustained contact with black African people as equals, in the form of the Shona people (cf. Prozesky 2000a). So, it is understandable that Prozesky would study (and advocate) religious pluralism. As he says, the ['strained'] 'religious diversity' of the world is a fact and does not need elaboration 'for we all know that the world is home to many kinds of religion' (Prozesky 2000b:180).

Given the plurality of religions, a curious matter, though, is 'why' there are religions. If we can answer this question, it would also answer the reason or reasons for why we have this plurality of religions, but also the

${ }^{6}$ Prozesky (1986b) uses the same kind of argument, but see too the next section. To this publication, cf. too Nürnberger's (1986) response, defending the then established Christian theologically-inspired 'National Initiative for Reconciliation'. 
diversity of religious orders, denominations, or what we may call religious tradition streams, trends or threads, within these religions. This was the question that he addressed in his book, Religion and Ultimate Well-Being: An Explanatory Theory (1984), and his article 'A Critique of Traditional Theistic Religion' (1985b) amongst others (cf. especially Prozesky 1986a; 1988). So, for him, the plurality of religions is intricately linked to the question of why the religions exist in the first place. In this section, we shall briefly address these two issues.

Firstly, in the second chapter of his book, 'Religion in Global Perspective', Prozesky compares some of the main world religions in order to come to an understanding of the "planetary representations of the most important, recurring characteristics of religion'. In a short piece, as part of this chapter, he also addresses the notion of 'The Plurality of Religious Traditions'. Central to his analyses and findings, is that even though variously stated, believed, and practiced, in the religious traditions - and also despite the historico-chronological transformations they underwent - the notion of 'wellbeing' - whether as a transcendental belief or a real-life expectation or experience - is central to all religious traditions on planet earth (Prozesky 1984: 23 - 50). Similar to his thought that informs and underlies this whole chapter, and this for his argument on the 'what', 'data' or 'explicandum' of the 'plurality of religious traditions', he identifies the following features or 'fundamental or essential properties' of 'all' these religious traditions (e.i.o.; cf. Prozesky 1988:304f). He says that,

... being religious includes participation in a specific tradition of ideas, actions, artifacts, roles, associations and institutions which express, facilitate and embody the believer's contact with or progress towards a superior order of reality ... (Prozesky 1984:60).

In a different publication, and saying that we need to keep an 'open mind' about the 'definition of religion', he also describes the religious traditions in terms of Wittgenstein's notion of 'family resemblances'. In terms of this perspective they all for example involve 'the use of mythology, ritual, belief in an invisible world, and so on' (Prozesky 1988:308). Explicating this more explicitly, he outlines the 'characteristics' of 'religion', as follows: 1) the 'benefit' religious traditions have for people - e.g. 'divine help with their problems'; 'comfort' in providing 'meaning and purpose' in life; 'certainty in 
the face of insecurity', 'healing', 'enlightenment', 'salvation'; 2) believers' 'sense of invisible, highly effective power at work in human experience and nature'; 3) that there is 'another order of reality [divine reality], more powerful, worthy and durable than mundane existence'; 4) that people 're-organizes their lives' in the light of their experience or 'felt presence' of this other worldly reality - in 'faith'; and 5) that all religions evince a 'cumulative tradition' through time (cf. Prozesky 1986a:30f). All these are experienced or are responses in the face of the 'dissatisfaction and misery' of the human condition (Prozesky1986a:35; cf. also 1988:305). As such, and this is repeated oft by Prozesky, this makes the manifestations of religion, human products (or at least partly so), and therefore subject to change - as has happened in history - and is required in the period of the transformation of apartheid Christianity to something else (Prozesky 1988:39).

On how his view of the plurality of religious traditions - together with their comparative differences and transformations through history - in the world impacts his main argument for seeking a reason or reasons for the 'explanation' of religion as such, he says:

An acceptable explanatory theory of religion must reflect these variations and say why human beings with their common, planetary quest for well-being and their common vision of a transcendental dimension none the less embody that quest and vision in such different systems or doctrine, ritual and institution (Prozesky 1984:61).

Secondly, the main question that Prozesky was asking, was not only regarding the 'plurality' of religions, but 'why' there is a phenomenon such as religion, in terms of the 'characteristics' outlined above - to 'explain' religion in terms of its cause(s). In order to proffer an 'explicans' for the 'explicandum', Prozesky turned to natural scientific Philosophical reasoning.

Science, he argues, uses 'logical explanations' based on 'deductive reasoning'. As such, it explains data in terms of the 'laws of nature'. In the case of the humanities and religion though, where we do not deal with the laws of nature, we use 'inference', and make 'inductive generalisations' (1984:70; 1988:306). And if we use this approach, with regard to explaining why there are these 'characteristics' or 'properties' of religion, we can answer why religion or the religions, exist. In the light of science, we have to produce 'the most probable inductive inferences' (1986a:33; 1988:306). He says: 
The explanatory quest thus [requires] ... a systematic, general theory made up essentially of the following components: one or more pervasive, fundamental regularities of human nature and of the cosmos at large, of such power and kind as to cause people to manifest whatever constant or recurrent properties we may find in the religions of the earth (for example, a ubiquitous concern with salvation, blessing, enlightenment and deliverance); plus an identification of the circumstances of history and culture which result in those regularities producing religious effects, plus an identification of the factors which are responsible for the various levels of differentiation in religion, whatever these may be judged to be (Prozesky 1988:307; cf. also 1986a:34).

For his explication of 'human nature' and 'the cosmos at large' he draws on Philosophical Anthropology and Philosophical Cosmology. He identifies and discusses as main features, 1) the variable experiences of human finitude; 2) human sentience, or our capacity to feel pain and pleasure or seek happiness á la Aristotle - that we respond with producing 'religion' and 'culture' in the face of 'discomfort', 'vulnerability', 'uneasiness' or 'anxiety'; 3) human creative responses by developing 'life-enhancing values', produce 'knowledge', invent 'concepts' [and we may add rituals and sacrifices] - all those human responses, that produce a 'betterment' of human existence as they struggle against 'dissatisfaction and misery', in their quest for the 'reduction of suffering'; and 4) the impact on humans of the environment, as constituted by 'everything that exists' - fellow human beings, and nature (Prozesky 1986a:34 - 37).

It is in the light of this explication that Prozesky then answers his question of the 'why' of religion, or the 'explanation' for the existence of something that we call religion. He says that central to the emergence of all human knowledge (including the production and experience of religion), is human cognition - to move from 'ignorance to knowledge', from the 'unknown to the known' - and that this forms part and parcel of the human 'learning process'. Central to this process is the production of knowledge and learning (also in religion and the developing of religious traditions) through our use of 'anthropomorphism', the human predisposition or inclination to explain the 'unknown by means of human and social or other familiar models'. In the face of the human experience of finitude and sentience, humans create [but also change or transform existing] knowledge. He says that the creation of 
knowledge and learning,

... yields a ... picture of humanity as constituted by its creative struggle to promote conditions in which misery is reduced and satisfaction is enhanced, but always within the limits of available knowledge, productive effort, ability to endure suffering, and realism in the assignment of values to things (Prozesky 1986a:36).

Such production of knowledge in the face of misery, Prozesky calls 'a basic fact about the way we are as persons'. He continues that he names this, a 'drive', or a 'desire', i.e.

... a drive to maximise well-being, a drive whose expressions are permanently restricted by our human finitude, but also permanently fuelled by our discontent it engenders. The search for an explanation of religion is largely a search for an adequate explicans, and I know of none more suitable on factual and logical grounds than this drive, though other factors are also involved [such as those arising from the environment] (Prozesky 1986a:36f).

For Prozesky, then, and this in the broad ambit of the 'naturalistic theory' of knowledge, the human 'drive to maximise well-being' or the 'desire for wellbeing', or for 'meaning in life', in the face of 'misery', constitute the 'explicans' or ensemble of 'causal factors' for the 'explicandum', the primary 'cause' or 'explanation' of religion (Prozesky 1988:307). In the case of religion, and given the strong religious commitments that characterise religious people, he labels this 'drive' or 'desire', the quest for 'ultimate well-being'. This 'drive' or 'desire', in his reasoning, in principle answers all the whyquestions of religious existence and religious experience - in all its manifestations, both transcendental understandings, and this-worldly real-life experiences. It also calls forth the 'dedication and seriousness of purpose that characterizes religious faith with accompanying re-organizations of [people's] lives to conform to the perceived will of the gods' - conversion and faith (Prozesky 1988:38). From this it also follows, that 'religion ... is our creation, therefore it is freely criticisable' and 'if defective, as all our creations to some extent are, it can be changed or relinquished'. This perspective on religion, so Prozesky argues, then also 'creates scope for transformation' (Prozesky 1988:39). 
'A Critique of Traditional Theistic Religion' (1985b), uses the same argument to discredit the 'traditional theistic religions', those who believe in a 'God' beyond time and space. In his mind, he has 'serious reservations about its value in our continued path to knowledge and well-being'. Talking personally about his 'standpoint', he says:

My priority is human well-being here on earth and in whatever subsequent existence, if any, lies ahead: and the highest goal I can conceive and strive for is a condition of maximal well-being for all. This gives my investigation an underlying religious orientation because religion is humanity's search for ultimate well-being (e.a. Prozesky 1985b:56).

We shall not rehearse the argument here. Suffice to say, that he explains, the notions of 'revelation', the cosmic 'forces' that affect us, the 'soteric' functions of the concept of God, as well as the notion of 'salvation' in terms of his objective, viz. to 'offer a picture of traditional theism as humanly-made and not divinely given'. All these notions constitute particular knowledges that the religions produced over millennia. They are also accompanied by certain practices - we may add, that materially manifest in systems, structures, institutions, rituals, attitudes, and behaviour. These diversity of knowledges and practices, also how they relate or not to secular ideology, show that,

... religious concern is inseparable from cognitive considerations .... But goals and insights on their own are powerless. There must also be action in ways that foster that goal. Thus a religious priority turns out to be incomplete without cognitive and practical components ... (e.a.; Prozesky 1985:56).

Apart from using the 'naturalistic theory', Prozesky also uses the notion of what we could call ethical 'practice' and as such, the ethical dimensions of the traditional theistic religions against them - i.e. in terms of the paradox or contradictions between that which they proclaim cognitively, and that what they ethically practice ${ }^{7}$. For instance, and pointing out that there is a new developing 'contemporary global awareness', he says:

${ }^{7}$ We have seen how this argument plays out in his critique of white Afrikaner Christian apartheid above. 
... theism is scientifically irrelevant and has sometimes been a nuisance; as modern Western history so grimly proves, it can coexist with policies of great national and individual wickedness; conversely, moral excellence is widely achieved without belief in God. Its traditional rational defence is rejected by virtually all except some whose belief never depended on it anyway; and most important of all, a mature spirituality can and does exist without it $^{8}$ (Prozesky 1985b:55).

This critique of theism was continued in his A New Guide to the Debate about God (1992), where he focused on 'The Case for the Believer' and 'The Case against the Believer', cross-religiously. John Hick (1993) reviewed and criticised Prozesky in terms of his own experientialist view of the existence of 'God' - i.e. 'religious experience'. Prozesy (1995a) countered, pointing out that his own 'evidentialist approach' to religion, is used by the experientialists themselves, where they distinguish between acceptable and 'delusory' religious experience - whether in the form of experiencing Hick's notion of 'the Real' theistically or non-theistically, the forms of the 'personae and impersonae of the Real' (Prozesky 1995a:55, referring to Hick 1989:233ff) ${ }^{910}$.

\section{Conscience Ethics}

As is evident from the two previous sections of this chapter, Prozesky has, in his academic life, developed experiences from his boyhood - experiences of

${ }^{8}$ Cf. Prozesky's (2006. Esp. p. 132ff) definition of secular spirituality and his assertion that the 'core value of the ethical and spiritual vision' he is exploring, is: 'Active concern for the wellbeing of all'.

${ }^{9}$ In recognition of the tremendous contribution Hick made to the study of Religion, Prozesky published an article in 2012, where he acknowledges the significance of the knowledge Hick produced and its international significance. He also raises five critical points from within the context of African traditional ethics (Murove 2009) and his own explanatory theory of religion (1984).

${ }^{10}$ Cf. also Prozesky's (1994) five point response to James Moulder's critique of A New Guide to the Debate about God from a 'logician's' perspective. Similar to his argument about 'religious experience', he also rightly criticises Moulder's argument for his 'apophatic' or 'logico-mystical' theology. 
the critique and rejection of apartheid, and an embracing of religious plurality. As he says, his notion of 'conscience' that he developed later intellectually, was already embedded in these early experiences - that '[apartheid] injustice is deeply wrong, and that all people deserve to be treated equally, caringly and fairly' (Prozesky 2000). His intellectual journey, brought him too, to not only foundationally question the existence of (traditional) theism, but also at least the claims of divine revelation, inspiration and origins of religion as such. ' $[\mathrm{M}]$ ostly with a sense of feeling the way ahead in the dark and being without a map for the journey ahead', in mid-life, he moved intellectually, as he says, 'from creed to conscience', and disciplinary speaking, from Religious Studies into Ethics Studies.

Whereas creed and conscience were previously a 'harmonious unity' for him, he found it necessary, in the light of his intellectual endeavours and the conclusions which he arrived at through his studies, to come to a point to 'deny creed in order to make room for conscience' (Prozesky 2000). Intellectually, Whitehead's implicit Philosophical Anthropology and Process Philosophy more generally speaking, were important partners on this journey (Prozesky 1995a; 1999). It also profoundly impacted his own development of process ethics, the main outcome of which, so far, is his Conscience: Ethical Intelligence for Global Well-Being (2007) ${ }^{11}$. For Prozesky, and in order to comprehend the discursive significance of Conscience, process thought provides an important alternative (and superior) starting point to develop a global ethics, i.e., supplanting the three global grand narratives that proved to be 'problematic'. These are:

- the liberal political and economic tradition - market sovereignty - with its advancement of individual sovereignty, and exaggerated emphasis on the individual, on the satisfaction of individual material interests, and personal profit (Prozesky 1995a:54; 2000: 187f; 1990:1f; 1999:2);

- the Marxian worldview or Marxism-Leninism with its materialist and collectivist conviction and concomitant suppression of private

${ }^{11}$ Even though there are only limited references to Whitehead and Process Philosophy in Religion and Ultimate Well Being, in our estimation, process thought is nevertheless present in Prozesky's work since 1979 when he briefly reviewed Process Theology: An Introductory Exposition, by John B. Cobb and D.R. Griffin - either explicitly, or implicitly sometimes. 
ownership of the means of production, and specific rights such as the freedom of speech and assembly (Prozesky 1995a:54; 1990:4f); and

- theism, with its subjection of individual responsibility to divine sovereignty and the obedience ethic, which reduces both human liberty and moral responsibility (Prozesky 1990:2-4; 1995a:54; 1999:3,7).

These grand narratives are problematic because of their convoluted notions of 'human existence':

Egocentric individualism, a problematic materialism, harm to egalitarian ideals, to the quest for human liberty and to nature; dualism, and a subtle undermining of the ideal of human responsibility by certain long-standing and pervasive theological notions (Prozesky 1995a:54).

Further, in describing the framework in which he develops his progressive process ethics, what we may call the global cultural trajectories that process ethics responds to, Prozesky lists five what he calls 'cultural trends or forces'. He then briefly discusses:

- the hegemony of the market as the de facto Grand Narrative of our time;

- the universal quest for egalitarian liberation that contests all forms of domination and subservience;

- the experience of cultural plurality vis-à-vis systems that propound cultural uniformity;

- the experience of deconstructive postmodernity that affirms difference and rejects the modernist project of creating a totally ordered world system; and

- secularisation, which rejects any claim of grounding ethics in any form of religion, and the experience and themes of which are prevalent in societies, in their this-worldly lifestyle, globally, whether we want to acknowledge it or not (e.i.o.; Prozesky 1999:2f; 1984:66).

These cultural trends, Prozesky (1999:3f) argues, have not only 'eroded' the obedience ethic of theism, but also caused a 'confused and contested ethical 


\section{Johannes A. Smit \& Denzil Chetty}

situation around us' - a 'sense that ethics is vanishing and that nobody knows how to prevent its demise'. To some extent, and including the wide variety of new illiberal absolutisms and fundamentalisms that exclude, reject, marginalise and exploit in the world, we can say that as forces impacting and pulling in different directions, they have caused a certain global ethical vacuum where there are no common ethical systems shared between people, nations and countries, that uphold a generally and globally recognised and accepted ethic. It is in this globally-experienced trans-cultural and trans-religious, hiatus, that we see Prozesky sensing the importance and developing of his process ethics, and his ethical notion articulated with 'conscience'. Together, his related publications form his 'project of reconstructing and enhancing a mature, postobedience morality in our time' or to 'reshape ethics amidst contemporary global realities' (Prozesky 1999:12ff, 4). For this, third part of this article, then, we reflect on Prozesky's linking of his process ethics to Whiteheadian thought (cf. Prozesky 1995a; 1999), and then explicate some of the main tenets of his Conscience (2007). The latter is not intelligible without the former.

Firstly, if the paradoxes and contradictions within the theistic religions - evident in the discrepancy between 'creed' and practice, or more broadly, theology and ethics - are indicators of 'deicide', then an uncompromising foundation without any inconsistencies need to be developed, in order to ground ethics. Some pointers in this direction are provided by the centrality of the notions of 'creativity' and 'inner or essential relatedness' in Whiteheadian thought. He regarded what we in short hand may call, cosmic creativity - which includes human creativity and human freedom of choice - as the "ultimate metaphysical category', the 'universal of universals characterizing ultimate matter of fact' (Whitehead [1929] 1969:21,25, in Prozesky 1995a:54). This captures the notion of 'becoming' central to his process thought. Faced with different options in reality, humans choose what they think would provide the greatest 'good' (or 'beauty'), the greatest 'enjoyment' for them, or the greatest 'self-realization', and then act accordingly. If such a choice, or choices and judgements, are valorized in experience, in practice, then humans will continue to make similar choices, and enact them, which, in our understanding, means a cumulative advancement of the self's benefits, wellness, comforts, security, concerns, or what Prozesky throughout his works inclusively calls, 'wellbeing'. This human quest for well-being, Prozesky calls 'valorizing agency' (cf. Prozesky 2000:183), and since all human beings - whether they want to know it or not - effect their choices in practice, this leads to both a diversity 
inherent in the well-being people experience, as well as the well-being they produce through the systems and structures they create - human beings' conditions of possibility so to speak. In process thought, such diversity is the outcome of cosmic creativity, and human liberty, and to be welcomed and appreciated, and not avoided, ignored or rejected.

Further, if this creativity also applies cosmically - as Whitehead's metaphysics contends - then it is not only human lives that change and transform continuously, but also the cosmos, as such. And this is where Whitehead's notion of 'inner-relatedness' comes in. If humans continuously seek to maximize their own individual well-being cumulatively, such wellbeing will only be experienced as fully as possible if they act in such a way that their actions would also maximally seek, impact or facilitate the maximal well-being of all others, i.e. both humans and the environment, or cosmos. On the contrary, if humans seek their own well-being selfishly or egoistically, this will result in neither their own or others' well-being, nor that of the cosmos. The choice between these two options, and their cumulative qualitative improvement of the quality of life of people - or not - is then in effect a choice between goodness, virtuousness, decency, kindness, honesty, integrity, security on the one hand and evilness, wickedness, mercilessness, cruelty, and selfishness on the other. In terms of the social ethical outcome of the choices one makes according to process thought would then exclude any form of discrimination on the basis of race, class or gender, or any other 'essentially divisive view of the human condition' (Prozesky 1995a:56).

In terms of the interrelated social ethics that derives from Process Philosophy, Prozesky adds 'truthfulness and effective action' to 'goodness'. Concomitantly, he then postulates three moral rules. These are:

- well-being can only be maximal - as we all want it to be - when it is fully [cosmically] inclusive and thus ethical;

- truthfulness [will assure] true and lasting well-being;

- effective action [will assure] well-being that is brought about [or produced], as we all want (Prozesky 2000:185f).

All-inclusive, or holistic, maximal well-being will then come about through the cumulative and continuously increasing of wellness of not only people, but also nature. For its ethical choices for the good in the human lifeworld, 
personally, but also socially and systemically (or structurally), Prozesky (2000:186 - 190) argues that people would seek the 'common good'. This needs to be the case in not only politics and economics, but also religion. In African culture, the inclusive and holistic ethic of ubuntu captures this ethos (Prozesky 2009a). And for ethical choices concerning their environments and nature, people should conserve, protect, maintain and sustain their ecosystems. In process thought, environmental or ecological ethics, therefore form an integral, ontological part of the quest for human well-being (cf. Prozesky 2009b). Murove (2009) has developed this notion in African context, with regard to the Shona concept of Ukama, that represents human 'social, spiritual and ecological togetherness'.

These two perspectives are then not only ontologically but also ethically interrelated in process thought. And, if we practice what we may call the eco-human ethics derived from process thought, it will produce and continuously increase human and natural wellness and well-being as we as humans continue to make rational and logical choices that affirm previous ones for goodness - with regard to fellow human beings as well as our environment, and nature $-\ldots$ those choices that have been experienced as bringing about goodness and well-being in practice. Prozesky (2000:185) calls this the 'valorizing of experience' in process ethics. And, since such a quest for well-being through learning from experience is also socially shared with fellow human beings in the process paradigm, for Prozesky, this is based on a shared power, or what he calls, the 'valorizing of power' (Prozesky 2000:185). The valorizing of socially-shared power is then the means through which humans collectively seek the best possible eco-human world and culture for themselves as well as all other living creatures - in Whiteheadian terms, 'peace', and for Prozesky, 'inclusive well-being' (cf. Prozesky 1995a:58). This stands in stark contrast to its opposite, viz. power as control, domination, exploitation, or power which is exercised through the obedience ethic, whether sanctioned divinely, scripturely, or secularly. In terms of religion, Prozesky (2000:188) says that,

... there must be a mixed verdict on religion, some of it being seen as ethical and some not, and the criterion to be used is clear: good religion is religion which gives maximum scope for intensities of fulfilled experience marked by creative diversity and which fosters and justifies spiritual convergence. If all power is shared power, then all saving power is also shared. 
In summary, we can follow Prozesky (1999:4) as he describes his process ethics as it relates to Whitehead, as,

... a call for us all to participate in the global cultivation of the kind of personal character and societies that will maximizes the enjoyment of beauty [goodness] for all in durable conditions of peace and truthfulness [well-being], which in Whitehead's metaphysics would constitute the fulfilment of the deepest potential of both human and cosmic processes.

Secondly, if we accept the foundational notions of cosmic creativity and the inner or essential relatedness of our eco-human world - in which humans participate, for better or worse - the question then arises as to whether it would be possible to develop a global ethic that would include (or better, transcend) the various forms of human cultural (including religious) diversity, deriving from the holistic inclusive eco-human quest for well-being. This is what Prozesky has been driving towards, and of which his Conscience: Ethical Intelligence for Global Well-being is a good example. Central to his argument is that 'conscience' is universal - all human beings have a conscience, and its existence and operation could be verified from 'sources' such as 'our shared humanity', the 'common core of sound, longstanding values in the world's religious faiths', our 'human nature' as verified by science, and the 'logical power of reason' ${ }^{\prime 2}$ (Prozesky 2007:31). Rather than reviewing the vast bulk of thought on the notion of 'conscience' since Plato (on Socrates) and Aristotle through history ${ }^{13}$, Prozesky's notion of conscience - or an 'ethical life' - is grounded in 'ordinary human experience'. He unpacks this view in chapter two of Conscience (2007:32 - 64).

Suffice to say, that in line with his process ethics, our ordinary human ethical choices (between good and evil) about which values to enact or practice and which not, would reflect or accumulatively repeat those similar ones that have been confirmed by our experience of earlier ones that resulted in feelings of goodness and well-being - especially those that gave us 'maximum' satisfaction. This would include choices regarding self-sacrifice and delayed

${ }^{12}$ These four 'sources' provide the thematic focuses for chapters $2-5$ of Conscience (2007).

${ }^{13} \mathrm{Cf}$. Schinkel (2007) for a good overview. 
satisfaction. This view on conscience, he argues, is corroborated by experiences of the faithful within specific religious traditions throughout history, but also 'brain science' or 'human neurobiology', with regard to our 'brain structures'. Central to such experience is our relationality - to wish maximum well-being for both self and other - but also our own ethical creativity. With regard to the common core of religious values - such as love, compassion, truthfulness, justice and sexual decency within and across the religions and their traditions (Prozesky 2007:28) - humanity has experienced, since its earliest founding and practicing of religious notions, that 'selfishness' and 'greed' self-destructs'. On the other hand, the practicing of values that wish for and affirm the well-being of others, including nature, attests to our commonly shared core values and practices related to 'generosity' and 'inclusive concern' of the other. These trans-religious values, including those processmatically affirmed in secular life and its philosophies, as well as in nontheistic religious cultural traditions are: generosity, integrity, truthfulness, respect, justice and fairness, inclusiveness, responsible caring effort, freedom and beauty. These values, and how they are practiced not only inside religions, but trans-religiously and especially in our increasingly secularized world, could well be the core of values that should undergird a global ethic. They transcend culture, religion, race, gender, ethnicity, and any other exclusionary social formation, and should be practiced inclusively of all. They also resonate with the values espoused in the globally significant declaration of a global ethic (Küng \& Kuschel 1993) as well as those advanced by Kidder $(1994)^{14}$ (Prozesky 2007:98 - 145). Individually speaking, these values - including those he himself advocate - should not remain rules and codes on paper, so to speak, but be actively practiced. As such, they could be operationalized as 'steps to personal growth' and character building (Prozesky 2007:148 - 164). A precondition, though is that we commit to the following:

- to strengthen our own moral character;

${ }^{14}$ The former was the outcome of the 1993 Parliament of the World's Religions in Chicago, and the latter a product of the U.S.A. Institute for Global Ethics, under the leadership of Rushworth M. Kidder. It needs to be pointed out though that Prozesky developed his own notion of a global ethic independently of these two proposals. 
- to ensure that our contacts with others - our relationships - foster wellbeing;

- to make our contexts - such as family and workplace - as humanly rich and supportive as possible;

- $\quad$ to value cultural diversity; and

- to use whatever controlling powers we have to foster strong ethical leadership (e.i.o. Prozesky 2007:147).

\section{Brief Concluding Reflections}

As said, we think Prozesky's thought, throughout the just over fifty years of his scholarly engagements, provide a very important corpus of knowledge both academic and practical - for the study of Religion and Ethics. This is so not only for South and southern Africa, but for the global South, as well as the so-called 'West', as Conscience (2007) argues. A more comprehensive analysis, interpretation, problematization, contextualization and further development of his thought and work is still outstanding. In order to assist in this endeavor, we make a few brief comments. For these, we shall remain within the parameters of this chapter ${ }^{15}$.

- Prozesky's unpacking and critique of apartheid need to be extended to other international socio-political systems articulated with religions or specific religious traditions within the (world) religions, as well as secular systems (such as exist in the U.S.A.). Amongst others - to be produced his focus on apartheid and critique of apartheid Christianity in the light of its own 'love ethic', can serve as test case or case study for others, focusing on fellow world religions or religious traditions. And, as he has done for the post-apartheid state, we need to continue to advocate for religious justice, or the equal accommodation of the religions, religious

15 As such, we are not dealing with Prozesky's publications after 2007. With regard to his notion of 'well-being', or rather, 'maximum well-being', readers are advised to especially consult his, in our opinion, very important publication in the Journal for the Study of Religion in 2014, as well as related publications after 2007, in which he reflects on 'ethics and the future'. 
traditions and their practices in the world's (nation) states (cf. Prozesky 1995b).

- His development of a global ethics can in theory be accommodated by all the world's religions and religious traditions, feminist ethics, secular mora-lities, eco-ethical movements, LGBTQ rights, or, in his words, the world's great current 'streams of consciousness' (Prozesky 2007: 131f). Yet, we need to see what the results are when we engage these from within Prozesky's global ethics, or his notion of 'ethical intelligence' - as captured in the tittle of Conscience - which all humans in principle share.

- Throughout his works, but especially in Conscience (2007), Prozesky frequently refers to important historical figures whose ethical choices and behaviour - following conscience - serve as global examples. These, amongst others, include Abraham Lincoln, Florence Nightingale, Mahatma Gandhi, Martin Luther King Jr. (impacted on by Gandhi amongst others), Nelson Mandela, and Archbishop Desmond Tutu. To our mind, these figures do not merely serve as examples, but represent the experiences and related ethical choices of people who lived in the same socio-political contexts. In terms of the global significance of their ethical choices - following conscience - their thought and choices, then serve as samples of what we would like to call global ethical experience. As such, it is the accumulation of global ethical experience - that ethical experience that transcends culture, race, gender, ethnicity, class, and other related exclusionary or demeaning social formations - that Prozesky has shown that cumulatively effects a global conscience, that basically usher in a global ethic. These examples and experiences have transcended those 'evil' systems which it opposed, such as Nazism, Stalinism, apartheid, American wars (such as under G.W. Bush), jihad intolerance and violence, amongst others. As Prozesky argued, these latter systems basically effect 'deicide' with regard to traditional theisms, and we can add 'the death of man' (Foucault 1970) with regard to secular cognitive disciplinary materialisms, in knowledge production and in practice.

- Closely related to the exemplary figures who exhibited a global conscience 
in history, are those individuals, social movements and formations, who, in the face of suffering and exploitation, did not propagate revenge and retribution, but values of equality, social and economic justice, freedom, truthfulness, fairness, honesty and generosity. In sum, these comprise inclusive interrelatedness that transcends evil - what Prozesky calls 'deep ethical value' or 'magnanimity' (cf. for example Prozesky 2007:100ff). Amongst these we may count the founders of the world religions, but in the twentieth century, also those who struggled against the various forms of colonial and neo-colonial, as well as apartheid oppressions, discriminatory practices and attitudes, and labor, agricultural, industrial and market exploitations. The test case for them and their followers, though is whether they have and continue to ethically transcend the evils they have experienced (as applicable), once in power.

- Concerning power, and since he has lived through, witnessed the effects and criticized apartheid, Prozesky on the one hand assumes implicitly or explicitly criticizes the notion of what we may call, 'power as domination' or 'power without conscience' (cf. for example Prozesky 2007:23). Such power is obvious in oppressive, discriminatory and exploitative systems, as was evident in apartheid and especially pertinently obvious in the perpetration of state violence during the times of so-called "national emergency'. Yet, he also advocates his notion of what he calls the 'valorizing of power' - shared power. This is very important since it assumes that people from diverse cultures and religions who act together - as we for instance saw in the various anti-apartheid and ecumenical movements in 1980s South Africa - may bring about the necessary and inevitable transformations longed for and required. Goodness will always triumph over evil.

- Further, and here we want to differ from Prozesky. He asserts that 'knowledge is power' (Prozesky 2007:99). He says this in the context of the progressive and increasing of the information age's production of systems for what we may call the democratization of knowledge and information. Just two points. This may be true for those systems that have 'goodness' and 'generosity' as aim. But it is equally true of those systems which sow ideological discontent, violence and brutality. Secondly, power articulates with knowledge or knowledges, through various 
systems - imaginary as well as materially - that can impact the quality of human life detrimentally. Many of these systems are systems we are currently living through in the world, and implicitly accept. The point though is, that they themselves are in need of critical scrutiny and critique, through what we may call, a critique of 'knowledge-power'.

- In our opinion, and concurring with Prozesky, we believe, no-one is exempt from the effects of secularization in the world. Over the last two decades it has especially impacted people in extremely diverse contexts through what we may call the democratization of knowledge and information globally. The so-called 'Arab Spring' is a case in point, and more closer to home, the '\#Feesmustfall student movement in South Africa. So, religions, and religious traditions, especially those cloistered and self-enclosed religions and religious traditions should open up to a larger understanding of the world - because that is happening in any case, whether we acknowledge it or not. And we think that this is where Prozesky's notion of conscience, also as we expounded it in this article, could be helpful. This would enhance the global humanness and ecological sensitivity and care we need interrelatedly as well as ecologically. As Prozesky advocates, for this we need leaders of character and commitment, leaders who articulate and represent socially and ecologically responsible decisions and who can lead by example.

- Granted that Prozesky was the founding director and head of the Unilever Ethics Centre, also contributed immensely to the ethics of accountants and auditors, and also sporadically refer to the impact of 'environment' (for good or ill) on people - together with colleagues, some of whom have published in this Festschrift - we need more ethically critical engagements of societies, organizations, companies, unions, businesses, clubs, corporations, political parties, etc. It is at this level, in our opinion, that the world globally, and South Africa more particularly suffer tremendously. Officials and functionaries are not held to account for their decisions, actions, and systems they create and enact. And, what we witness is that so-called systemic corruption and eco-destruction, is rampant. In addition to the fostering of a global ethic of character and commitment ('inwardness'), we need a global ethic of organizational responsibility and responsivity a global ethic of externality or 
outwardness. We need collective values in terms of which we, the global populace can hold these companies, political formations, power-holders and fellow socio-religious formations to account.

- Prozesky is well known for championing the notion of 'well-being' to capture both the transcendental realities we as humans create to represent our most inner wishes for 'ultimate' or universal wellness but also our this-worldly wellness. We shall not say anything further on this, except for linking this to Prozesky's notion of conscience. In a number of contexts in Conscience (and in some of his other publications), Prozesky suggests that our consciences are not given once and for all. A conscience is subject to 'learning', 'growth', and a process of 'maturation' (cf. for instance 2007:50,69,88,113,149. As such, he also applies this to the epochs of human existence, saying that our current secular phase is the latest such epoch or phase of human ethical life. As phase, it also captures Geering's (1991) distinctions between ethno- or indigenous, trans-ethnic and secular/ global moralities (cf. Prozesky 133 - 136). In the face of our globalising world, we think, these distinctions are helpful ${ }^{16}$. The important point, though is the emphasis that Prozesky places on the learning aspect of conscience or ethical living or 'ethical fitness'. Apart from growing up in ethically responsible households - as he himself has experienced - we also importantly need the putting in place and practicing of learning or educational systems that foster ethical or conscientious living, and that globally.

- Finally, about the notion of transformation, we want to raise two issues. Firstly, Prozesky uses this concept to refer to personal transformation, i.e. to come to 'faith' or conversion. Now this is a specifically religious experience, and to our mind prevalent in all the religions and religious traditions of the world, and in various forms of manifestation, and incidence. We think Prozesky does not make enough of this in his theorizing of conscience. And, if we need to convince others about the importance of a coming to or even 'converting to' a global ethic, then such

${ }^{16}$ In terms of our post-modern condition, we have to keep these together as they are believed and practiced alongside each other, or in different hybridities - not without the requisite critique though. 
an 'experience' need to be worked for in more social formations globally than at present. In this endeavor, what we called 'global ethical experience', or following Prozesky we can call it 'deep ethical experience', is important. Secondly, we have lived through and witnessed the transformation of South Africa from the rule, control and dominance of a racist white minority regime to a non-racial, non-sexist, and nonsectarian democratic dispensation. We have also seen a new Constitution, and democratic elections. Yet, the structural inequality that we inherited from the oppressive and exploitative colonial and apartheid systems, continue to produce wide-spread and abject poverty. We believe, that in South Africa, there is no greater challenge than this for our generation. We also believe that academe should provide intellectual leadership produce the requisite discourse and discursive practices - that could effect radical socio-economic transformation structurally and in practice, at the different socio-economic levels needed in this regard. As such we can talk of the quest for socio-economic well-being in South and southern Africa, but also globally speaking.

Above and beyond the significance and impacts Prozesky's thought has already had, it will undoubtedly continue in future, and that globally. This is especially so for what we may call a Prozeskyan philosophical anthropology of the human 'drive to maximize well-being'. In his thought, with this notion - which can be applied to both the multiple and variable human quests for 'ultimate' and/ or this-worldy existential well-being, collectively, and in harmony with nature, - he completes what Whiteheadian metaphysics and a process ethics lack. Whitehead has not developed a 'teleology' of human existence. As such, his metaphysics as well as his philosophical anthropology - his 'position on human existence and human nature' - is 'in some respects incomplete' (cf. Prozesky 1995:59). With the various analyses, arguments and contextualisations, with which Prozesky has advanced his own notion of 'wellbeing' over more than forty years of work, Prozesky though, made his own distinctive, unique and insightful contribution to, but also moved beyond, both process metaphysics and ethics. He in fact, produced what Whitehead lacked. And while we live through a period characterized by the 'incredulity towards meta-narratives' (Lyotard 1984), not least colonizing meta-narratives, and narratives of empire, you have made your mark, and made it decisively, Martin. We honour you for that Martin, not least, your bravery. 


\section{Acknowledgements}

* Prof J.A. Smit wants to thank the University of KwaZulu-Natal for the sabbatical during which he could do the research and write-up this article, amongst others.

* We would also like to extend our sincere gratitude for the multiform assistance and help that we have received from Ms. Faith Bhengu, UKZN Principal Librarian (Durban), Ms. Celeste Johns, Circulation Supervisor, Mr. John Timms, Circulation Desk (Interlibrary Loans), and Mss. Shanitha Bhim and Bronwyn Tayler, Circulation Desk, Gita Ramdass, Archives, and Sherian Latif, Alan Paton Centre and Struggle Archives (Pietermaritzburg).

\section{References}

de Gruchy, J. \& C. Villa-Vicencio (eds.) 1983. Apartheid is a Heresy. Cape Town and Johannesburg: David Philip.

de Gruchy, J. \& M. Prozesky (eds.) 1991. A Southern African Guide to World Religions. Cape Town: David Philip.

Foucault, M. [1966] 1970. The Order of Things: An Archaeology of the Human

Sciences. Unknown (trans.). New York: Pantheon.

Geering, L. 1991. Creating the New Ethic. Wellington: St. Andrew's Trust.

Hick, J. 1989. An Interpretation of Religion: Human Responses to the Transcendent. London: Macmillan.

Hick, J. 1993. Review of: A New Guide to the Debate about God. Journal for the Study of Religion 6,2,September:113ff.

Kidder, R.M. 1994. Shared Values for a Troubled World: Conversations with Men and Women of Conscience. San Francisco: Jossey-Bass Publishers.

Küng, H. \& K-J Kuschel (eds.) 1993. A Global Ethic: The Declaration of the Parliament of the World's Religions. London: SCM Press.

Lyotard, J-F. [1979] 1984. The Postmodern Condition: A Report on Knowledge. Bennington, G. \& B. Massumi (trans.). Minneapolis: University of Minnesota Press.

Moulder, J. 1994. Oversights: A Logician's Response to Martin Prozesky's Natural Theology. South African Journal of Philosophy 13,1: 34 - 36.

Murove, M.F. 2009. An African Environmental Ethic Based on the Concepts of Ukama and Ubuntu. In Murove, M.F. (ed.): African Ethics: An Anthology of Comparative and Applied Ethics. Pietermaritzburg: University of KwaZulu-Natal Press. 
Nürnberger, K. 1986. Can Christians Overcome Apartheid - Except as Christians? A Response to Martin Prozesky's Evaluation of the National Initiative for Reconciliation. Journal for the Study of Religion 54:56 - 60 . Prozesky, M. 1979. Process Theology: An Introductory Exposition, by John B.

Cobb Jr. and David Ray Griffin. Journal of Theology of Southern Africa 26,March: 76.

Prozesky, M. 1984. Religion and Ultimate Well Being: An Explanatory Theory. London \& New York: Macmillan, and St Martin's Press.

Prozesky, M. [1985a] 1990. Implications of Apartheid for Christianity in South Africa. In Prozesky, M. (ed.): Christianity Amidst Apartheid: Selected Perspectives on the Church in South Africa. London: Macmillan.

Prozesky, M. [1985a] 1990. SA Edition: Christianity in South Africa, published by Southern Book Publishers, 1990.). The original paper was: 'Christianity and Apartheid: From Christian Deicide to Socio-Political Salvation in South Africa' at the conference on 'Salvation and the Secular'.

Prozesky, M. 1985b. A Critique of Traditional Theistic Religion. South African Journal of Philosophy 4,2,May: 55 - 61.

Prozesky, M. 1986a. Philosophical Cosmology and Anthropology in the Explanation of Religion. Theoria 66,May: 29ff.

Prozesky, M. 1986b. Can Christians Overcome Apartheid? An Evaluation of the 'Statement of Affirmation' of the National Initiative for Reconciliation. Journal for the Study of Religion 54:53 - 55.

Prozesky, M. 1988. Explanations of Religion as Part of and Problem for Religious Studies. Religious Studies 24: 303ff.

Prozesky, M. 1990a. Christianity Amidst Apartheid: Selected Perspectives on the Church in South Africa. London: Macmillan.

Prozesky, M. 1990a. SA Edition: Christianity in South Africa. Halfway House:

Southern Book Publishers.

Prozesky, M. 1992. A New Guide to the Debate about God. London: SCM.

(Also published in Pietermaritzburg by University of Natal Press.)

Prozesky, M. 1994. Gift or Delusion? A Reply to James Moulder's Logicomysticism. South African Journal of Philosophy 13,1: 36-38.

Prozesky, M. 1995a. Experientialist and Evidentialist Approaches to the Justification of Theism. Journal for the Study of Religion 8,2,September: 47-58.

Prozesky, M. 1995b. Religious Justice at Last? Believers and the New 
Constitution in South Africa. Journal of Theology of Southern Africa 92: $11-21$.

Prozesky, M. 2000a. From Creed to Conscience and The Constitution of South Africa. Available at: http://sof.org.nz/prozesky.htm

Prozesky, M. 2000b. Ethical Creativity in a Culture of Uneasy Religious Pluralism, Incomplete Democratization and Economic Justice. In Cochrane, J. \& B. Klein (eds.): Sameness and Difference: Problems and Potentials in South African Civil Society. Washington: The Council for Research in Values and Philosophy.

Prozesky, M. 2006. Ethics, Spirituality and the Secular. In Du Toit, C.W. \& C.P. Mayson (eds.): Secular Spirituality as a Contextual Critique of Religion. Pretoria: University of South Africa.

Prozesky, M. 2009a. Cinderella, Survivor and Saviour: African Ethics and the Quest for a Global Ethic. In Murove, M.F. (ed.): African Ethics: An Anthology of Comparative and Applied Ethics. Pietermaritzburg: University of KwaZulu-Natal Press.

Prozesky 2009b. Well-fed Animals and Starving Babies: Environmental and

Developmental Challenges from Process and African Perspectives. In Murove, M.F. (ed.): African Ethics: An Anthology of Comparative and Applied Ethics. Pietermaritzburg: University of KwaZulu-Natal Press.

Prozesky, M. 2012. John Hick's Interpretation of Religion: A Perspective from South Africa. Journal for the Study of Religion 25,1: 5-13.

Prozesky, M. 2014. Homo Ethicus: Understanding the Human Nature that Underlies Human Rights and Human Rights Education. Journal for the Study of Religion 27,1: 283 - 301. Available at:

http://www.scielo.org.za/scielo.php?script=sci_issuetoc\&pid=1011760120140001

Prozesky, M. \& J. de Gruchy (eds.) 1995. Living Faiths in South Africa. Cape Town: David Philip Publishers. (Co-published by Hurst in London and St. Martin's Press in the USA.)

Schinkel, A. 2007. Conscience and Conscientious Objection. Amsterdam: Vrije Universiteit. Available at:

https://books.google.com.gi/books?id=5B1AeeopDRUC\&printsec=front cover\&dq=editions:OCLC633299067\&vq=\%22Hegel $\% 22 \&$ source $=$ gbs citations module $\mathrm{r} \& \mathrm{cad}=3 \# \mathrm{v}=$ onepage $\& \mathrm{q}=\% 22 \mathrm{Hegel} \% 22 \& \mathrm{f}=$ false

Smit, J.A. \& B. Vencatsamy 2012. Religion in the Humanities. Alternation Special Edition 10: 270 - 318. Available at: 
Johannes A. Smit \& Denzil Chetty

http://alternation.ukzn.ac.za/Files/docs/20.7/13\%20Smi.pdf

Whitehead, A.N. [1929] 1969. Process and Reality: An Essay on Cosmology. London: Macmillan; 1969. New York: The Free Press.

Johannes A. Smit

Religion \& Social Transformation School of Religion, Philosophy and Classics University of KwaZulu-Natal smitj@ukzn.ac.za

Denzil Chetty Department of Religious Studies \& Arabic College of Human Sciences University of South Africa chettd@ukzn.ac.za 